\title{
Mycorrhizal fungi inoculation and phosphorus fertilizer on growth, essential oil production and nutrient uptake in peppermint (Mentha piperita L.)
}

\author{
ARANGO, M.C. ${ }^{1}$; RUSCITTI, M.F. ${ }^{1}$; RONCO, M.G. ${ }^{1,2}$; BELTRANO, J. ${ }^{1,2 *}$ \\ ${ }^{1}$ Instituto de Fisiología Vegetal (INFIVE, CCT LA PLATA-CONICET), Universidad Nacional de La Plata, C.C. 327, \\ 1900 La Plata, Argentina, ${ }^{2}$ CIC-PBA *jbeltrano@agro.unlp.edu.ar
}

\begin{abstract}
RESUMO: Inoculação com fungos micorrízicos e adubação fosfatada no crescimento, produção de óleo essencial e absorção de nutrientes em hortelã-pimenta (Mentha piperita L.). Este estudo avaliou os efeitos da inoculação de fungos micorrízicos arbusculares Glomus mosseae, Glomus intraradices $\mathrm{A}_{4}$ e Glomus intraradices $\mathrm{B}_{1}$ e duas doses de fósforo $(10$ e $40 \mathrm{mg}$ $\mathrm{kg}^{-1}$ ) sobre a colonização radicular, crescimento, absorção de nutrientes e óleos essenciais em Mentha piperita L. O estudo foi conduzido em casa de vegetação no delineamento inteiramente casualizado em esquema fatorial $4 \times 2$. Sessenta dias após o transplantio, as plantas micorrizadas apresentaram massa fresca, massa seca, e área foliar significativamente maior em comparação as não-micorrizadas. A inoculação aumentou o teor de $\mathrm{P}, \mathrm{K} \mathrm{e} C$ a na parte aérea sendo superiores em $40 \mathrm{mg} \mathrm{P} \mathrm{kg}^{-1}$ de solo. As plantas cultivadas com $40 \mathrm{mg} \mathrm{P} \mathrm{kg}^{-1}$ de solo aumentaram a produção

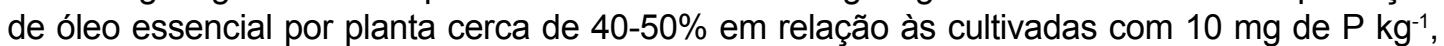
independentemente da micorrização. Dentre as espécies fúngicas estudadas, a inoculação com $G$. Intraradices $\mathrm{A}_{4}$ e com um elevado nível de $\mathrm{P}$, aumentou significativamente o crescimento e rendimento de óleos essenciais em comparação com outras espécies de fungos micorrízicos estudados. Em conclusão, a inoculação dos fungos micorrízicos arbusculares em plantas de hortelã é uma alternativa viável para aumentar a produção de óleos essenciais e reduzir o uso de fertilizantes necessários para a produção econômica de hortelã-pimenta com deficiência de fósforo no solo.
\end{abstract}

Palavras-chave: adubação fosfatada, Glomus mosseae, Glomus intraradices, Mentha piperita, óleo essencial

\begin{abstract}
This study evaluated the effects of inoculation with the arbuscular mycorrhizal fungi Glomus mosseae, Glomus intraradices $\mathrm{A}_{4}$ and Glomus intraradices $\mathrm{B}_{1}$ and two phosphorus levels (10 and $40 \mathrm{mg} \mathrm{kg}^{-1}$ ) on root colonization, plant growth, nutrient uptake and essential oil content in Mentha piperita $\mathrm{L}$. The experiment was carried out in a greenhouse, in $4 \times 2$ factorial arrangement, in completely randomized design. At sixty days after transplanting, the mycorrhizal plants had significantly higher fresh matter, dry matter and leaf area compared to non-mycorrhizal plants. The inoculation increased $\mathrm{P}, \mathrm{K}$ and Ca levels in the shoot which were higher under $40 \mathrm{mg} \mathrm{P} \mathrm{kg}^{-1}$ of soil. Plants grown with $40 \mathrm{mg} \mathrm{P} \mathrm{kg}^{-1}$ soil increased the essential oil yield per plant by about $40-$ $50 \%$ compared to those cultivated with $10 \mathrm{mg} \mathrm{P} \mathrm{kg}^{-1}$, regardless of the mycorrhizal treatment. Among the studied fungal species, inoculation with $G$. intraradices $\mathrm{A}_{4}$ and a high level of $P$ significantly increased plant growth and essential oil yield, compared to the other studied mycorrhizal fungal species. In conclusion, inoculation of arbuscular mycorrhizal fungi into peppermint plants is a feasible alternative to increase the essential oil production and reduce the use of fertilizers required to obtain economic production of peppermint under phosphorus-deficient soil condition.
\end{abstract}

Key words: phosphorus fertilizer, Glomus mosseae, Glomus intraradices, Mentha piperita, essential oil

\section{NTRODUCTION}

Mentha piperita L. (peppermint) is an herbaceous plant of the family Lamiaceae that can be used in numerous forms. Its cultivation has economic importance due to its capability of producing and storing essential oils, whose main constituents are menthol and menthone. Peppermint is used in the pharmaceutical, food and cosmetic industry. Several authors have reported antioxidant,

Recebido para publicação em 23/08/2011

Aceito para publicação em 02/04/2012

Rev. Bras. PI. Med., Botucatu, v.14, n.4, p.692-699, 2012. 
insecticidal, antifungal and antibacterial activity of mint essential oils (Souza et al., 1991; Sokoviæ et al., 2009; Derwich et al., 2010; Kumar et al., 2011).

Arbuscular mycorrhizal fungi (AMF) are the most common type of mycorrhizal association (Hodge, 2000). This association allows plants to explore larger volumes of soil, expanding the area of root absorption, increasing the area of contact with the soil, favoring the absorption of water and nutrients, especially $P$, and stimulating plant growth (Bressan et al., 2001; Gupta et al., 2002). The responses of the mycorrhizal plants related to $P$ concentration in the soil vary with the species and the genotypes (Clement \& Habte, 1995).

Arbuscular mycorrhizal fungi are known to play an important role in the nutrition and in the growth of plants in many production-guided agricultural systems, but little is known about their potential effect on secondary metabolites in medicinal and aromatic plants (Copetta et al., 2006; Khaosaad et al., 2006; Kapoor et al., 2007).

Studies of Ocimum basilicum (Khaosaad et al., 2006) and Artemisia annua (Kapoor et al., 2007) have shown that root colonization by AMF increases essential oil content and quality. However, little is known about the effect of AMF, $P$ availability and nutrient uptake on essential oil content in M. piperita. Sirohi \& Singh (1983) reported better root infection, higher biomass, $P$ uptake and essential oil yield in M. piperita when associated with Glomus fasciculatus, compared to non-inoculated plants. Moreover, Gupta et al. (2002) concluded that inoculation with the AMF G. fasciculatum significantly increased root colonization, growth, essential oil yield and nutrient uptake in M. arvensis. Freitas et al. (2004) also observed that inoculation with AMF provided increments of up to $89 \%$ in the essential oil content in mint plants ( $M$. arvensis) in relation to noninoculated plants. Meanwhile, Maia (1998) determined that $\mathrm{N}$ and $\mathrm{P}$ deficiencies drastically reduced the production of fresh biomass and affected the essential oil composition in M. arvensis. From an agricultural point of view, mycorrhizal associations are important because they reduce the cost and the environmental contamination with chemical fertilizers (Azcón-Aguilar \& Barea, 1997).

The aim of the present study was to evaluate the comparative effects of different species of mycorrhizal fungi and phosphate fertilization on growth, essential oil production and mineral composition in M. piperita plants.

\section{MATERIALAND METHOD}

Plant material and growth condition: Experiments were carried out in a greenhouse at INFIVE, La Plata, Argentina (34 52' S; $57^{\circ} 58^{\prime} \mathrm{W}$ ), between September 2007 and February 2008, under natural day length. Temperatures during the experiment were between the maximum $29.1^{\circ} \mathrm{C}$ in January $/ 08$ and the minimum $10^{\circ} \mathrm{C}$ in November/07 (Figure 1).

Apical shoots of $M$. piperita were obtained from the aromatic plant collection of the Biochemistry and Phytochemistry Laboratory (Faculty of Agricultural and Forest Science, University of La Plata, Argentina). The cuttings (10 cm long with two nodes and two pair of leaves) were surface sterilized in $0.5 \%$ sodium hypochlorite for $10 \mathrm{~min}$, rinsed twice with sterile water and placed in plastic cells containing a sterile mix of perlite and vermiculite [1:1 (v/v)] and irrigated by sprinkling every day for rooting.

Inoculation period: Rooted cuttings were

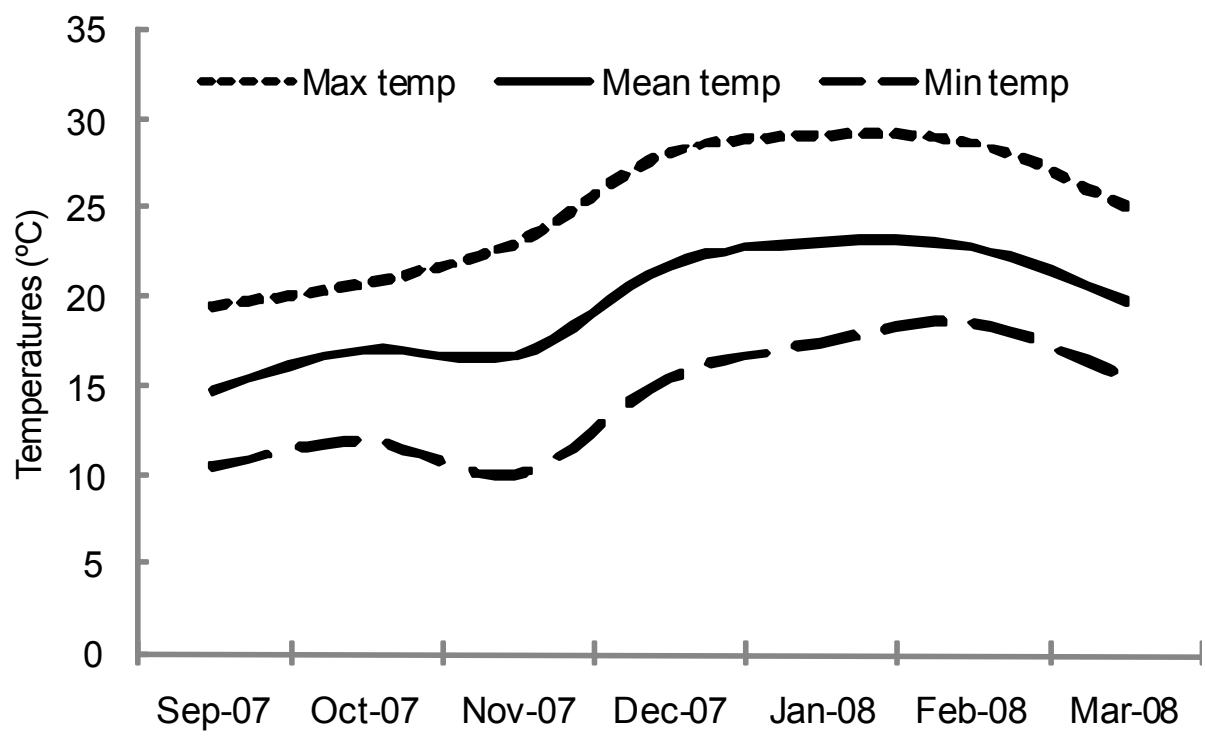

FIGURE 1. Monthly maximum, mean and minimum temperatures during the experimental period. 
transplanted into $250 \mathrm{~mL}$ plastic pots (one per pot). The substrate was a mixture of sand: soil (1:1) which was tyndallized at $100^{\circ} \mathrm{C}$ for 60 minutes, on 3 consecutive days. The used soil was an argiudol vertic: pH: 5.5; E.C: 0.91 mmhos. $\mathrm{cm}^{-1}$; P: $10 \mathrm{mg} \mathrm{kg}^{-1}$; K 0.95 meq.100 g soil-1; Ca 4.90 meq.100 g soil- $^{-1}$; organic matter: $3.5 \%$ and total N: $0.24 \%$.

The rooted cuttings were planted into a hole where the inoculum ( $20 \mathrm{~g}$ per plant) was previously added. The inoculum was a mix of substrate, spores (between 40-70 spores $\mathrm{g}^{-1}$ inoculum), mycelium and colonized root fragments (Trifolium repens L.) of Glomus mosseae (Mmos) (isolate SB1, Spegazzini Institute Collection, UNLP), Glomus intraradices, isolate $A_{4}\left(\mathrm{MintraA}_{4}\right)$ or Glomus intraradices, isolate $B_{1}\left(\right.$ MintraB $\left._{1}\right)$ (Glomeromycota In Vitro Bank, BGI, Buenos Aires, Argentina). The same amount of sterilized inoculum plus $10 \mathrm{~mL}$ mycorrhizal fungalfree filtrate from the inoculum suspension was added to non-inoculated pots in order to provide the same substrate conditions. After 40 days, 10 of each of the non-inoculated $(\mathrm{NI})$ and inoculated $\left(\mathrm{Mmos}, \mathrm{MintraA}_{4}\right.$, MintraB $_{1}$ ) plants were harvested and mycorrhizal colonization and growth parameters were determined.

Growth period: The remaining plants (15 plants of each treatment) were then transferred to 3 $\mathrm{kg}$ plastic pots into a mixture of sand:soil (1:1) (the same as that for the inoculation period), tyndallized at $100^{\circ} \mathrm{C}$ for $60 \mathrm{~min}$ on 3 consecutive days (Wolf et al., 1989; Barea et al., 1983). The plants were cultivated at two levels of $P: 10 \mathrm{mg} \mathrm{kg}^{-1}(-P)$ or $40 \mathrm{mg}$ $\mathrm{kg}^{-1}(+\mathrm{P})$ as $\left(\mathrm{KH}_{2} \mathrm{PO}_{4}\right)$. At flowering stage (60 days after transplanting), the plants were harvested and observations were recorded.

Estimation of mycorrhizal colonization: Fungal colonization was evaluated according to Trouvelot et al. (1986) and expressed as mycorrhization percent (M\%). The roots were cleared with $10 \%(\mathrm{w} / \mathrm{v}) \mathrm{KOH}$ and stained with trypan blue in lacto-phenol (Phillips \& Hayman, 1970). Three replicates of 30 randomly chosen root fragments (1 $\mathrm{cm}$ long) were mounted on slides and examined microscopically. The $M \%$ was calculated as the proportion of infected roots over total number of root fragments. The efficiency of mycorrhizal colonization was estimated by mycorrhizal dependence (MD), which related the biomass of inoculated plants to that of non-inoculated plants grown under the same conditions; it was calculated as:

$M D=\underline{D W}$ inoculated plants $-D W$ non-inoculated plants $\times 100$ DW inoculated plants

Growth parameters: Harvesting of material for determination of shoot fresh (FW) and shoot dry weight (DW) of leaves and stems was conducted between $7 \mathrm{~h}$ and $8 \mathrm{~h}$ in the morning, according to Freitas et al. (2004). DW was obtained by drying the material in oven at $40^{\circ} \mathrm{C}$ until constant weight. Leaf area (LA) per plant (Li 3000 leaf area meter, LICOR, Lincoln, NE, USA) was measured.

Mineral nutrient content: Nutrient content in shoot dry matter was determined at the end of the experiment. Total $\mathrm{N}$ was determined by micro Kjeldahl distillation. Phosphorus content was measured by the molybdovanadophosphate method (Kitson \& Mellon, 1944). Potassium (K) and Calcium (Ca) levels were measured with a flame photometer as described by Haddad \& Higginson (1990).

Extraction of essential oils: At flowering stage (60 days after transplanting), the plants were harvested and the essential oils (EO) in the shoot were determined by a hydro-distillation method on Clevenger-type apparatus for $3 \mathrm{~h}$ of each treatment (Maia, 1998). Essential oil content was calculated as $\mathrm{mL}$ of oil per $100 \mathrm{~g} \mathrm{DW}$ and oil yield, as $\mathrm{mL}$ of oil per plant. For the extraction of essential oils, the plants were harvested between $7 \mathrm{~h}$ and $8 \mathrm{~h}$ in the morning according to Freitas et al. (2004).

Statistical analysis: The experiment was in $4 \times 2$ factorial arrangement, with four mycorrhizal levels $\left(\mathrm{Nl} ;{\text { Mmos; } \text { MintraA }_{4} \text {; MintraB }}_{1}\right.$ ) and two phosphorus levels (-P: 10 and $+P: 40 \mathrm{mg} \mathrm{kg}^{-1}$ ) with 15 replicates (one plant/pot) per treatment in a completely randomized design. All data were analyzed using Analysis of Variance (ANOVA). The Tukey's test $(p<0.05)$ was used to evaluate the differences between treatments and interaction means, using SigmaStat 3.5 software (Systat Sofware, Inc, USA). For statistical analysis, all percentage values were transformed to arcsine, since this transformation remarkably improves variance homogeneity. The number of replicates was $\mathrm{n}=3$ replicates of 30 root fragments for mycorrhizal observations.

\section{RESULT AND DISCUSSION}

\section{Inoculation period}

None of the non-inoculated plants were colonized by Glomus species. At 40 days, mycorrhization was 36,63 and $80 \%$ for Mmos, MintraA $_{4}$ and MintraB $_{1}$, respectively, indicating that peppermint is a mycotrophic species.

The fresh and dry weigh and the leaf area of plants inoculated with $G$. intraradices $A_{4}$ and $B_{1}$ were higher than those of plants inoculated with $G$. mosseae and non-inoculated plants. MintraA $\mathrm{A}_{4}$ and MintraB $_{1}$ increased dry weight by $49 \%$ and $33 \%$, respectively, compared to non-mycorrhizal ones; leaf area increased by $45 \%$ and $39 \%$, respectively (Table 1 ). At forty days after inoculation, the highest mycorrhizal dependence was observed in MintraA $\mathrm{A}_{4}, 35.8 \%$, and the lowest one was detected in Mmos (11.4\%). 
TABLE 1. Growth parameters (fresh weight, FW; dry weight, DW and leaf area, LA) and mycorrhizal dependence $(\mathrm{MD} \%)$ in Mentha piperita plants inoculated with Glomus mosseae (Mmos), Glomus intraradices $\mathrm{A}_{4}\left(\mathrm{Mintr}_{4}\right)$ and Glomus intraradices $\mathrm{B}_{1}\left(\right.$ MintraB $\left._{1}\right)$; 40 days after inoculation.

\begin{tabular}{ccccc}
\hline Treatments & FW $(\mathrm{g})$ & DW $(\mathrm{g})$ & LA $\left(\mathrm{cm}^{2}\right)$ & MD $(\%)$ \\
\hline $\mathrm{NI}$ & $2.65 \mathrm{a}$ & $0.406 \mathrm{a}$ & $88 \mathrm{a}$ & --- \\
Mmos $_{\text {MintraA }}$ & $2.84 \mathrm{a}$ & $0.460 \mathrm{a}$ & $96 \mathrm{a}$ & $11.4 \mathrm{a}$ \\
MintraB $_{1}$ & $4.21 \mathrm{~b}$ & $0.608 \mathrm{~b}$ & $137 \mathrm{~b}$ & $35.8 \mathrm{c}$ \\
\hline C.V.\% & $3.55 \mathrm{~b}$ & $0.539 \mathrm{~b}$ & $123 \mathrm{~b}$ & $25.7 \mathrm{~b}$ \\
\hline
\end{tabular}

\# Mean values followed by the same letter in each column are not significantly different according to Tukey's test (5\%).

\section{Growth period}

At sixty days after transplanting, the percentage of root colonization varied between the fungi and the phosphorus fertilized soil. Mmos and MintraB $\mathrm{B}_{1}$ decreased $\mathrm{M} \%$ by $14 \%$ under $+\mathrm{P}$, compared to $-\mathrm{P}$, while MintraA $_{4}$ did not show significant differences between phosphorus treatments (Figure 2). Other authors also reported the negative effect of the phosphorus increment on the percentage of colonized roots, and that effect depends not only on the plant species but also on the fungal species (Nogueira \& Cardoso, 2000; Bressan et al., 2001; Kapoor et al., 2007).

AMF inoculation and/or phosphorus fertilization had a significant effect on all measured plant growth variables. However, the level at which plant growth was enhanced varied between the fungal inoculants. The fresh and dry weight of inoculated plants were significantly higher than that of noninoculated plants, regardless of $P$ level, in agreement with Abdul-Khaliq et al. (2001) and Cabello et al. (2005). For $+P$ treatment, the fresh and dry weight significantly increased in non-inoculated and inoculated plants, compared to -P treatment. In noninoculated plants, the dry weight increment was by $37 \%$, whereas in Mmos it was by $39 \%$, in MintraA $_{4}$ by $51 \%$ and inMintraB ${ }_{1}$ by $43 \%$ (Table 2 ), in agreement with Jackson et al. (2002), who demonstrated the beneficial effects of AMF in soils with low nutrient conditions, especially $P$. The increment of the phosphorus level in the soil increased the leaf area in both non-mycorrhizal and inoculated plants. Nonmycorrhizal plants showed the lowest values, regardless of the P level (Table 2). Our data showed a significant interaction between fungal species and $P$ levels on dry matter production and leaf area.

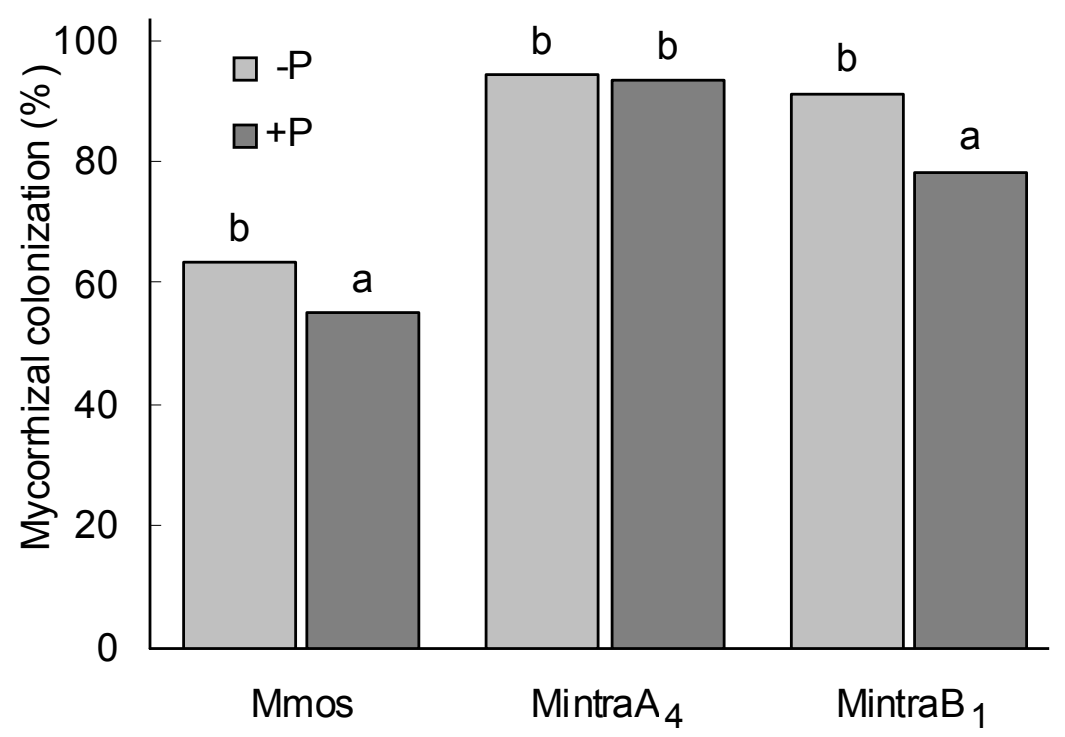

FIGURE 2. Mycorrhizal colonization in Mentha piperita plants inoculated with Glomus mosseae (Mmos), Glomus intraradices $\mathrm{A}_{4}\left(\right.$ Mintr $_{4}$ ) and Glomus intraradices $\mathrm{B}_{1}\left(\right.$ MintraB $\left._{1}\right)$ with two $\mathrm{P}$ levels (-P: $10 \mathrm{mg} \mathrm{P} \mathrm{kg}^{-1}$, soil $+\mathrm{P}: 40 \mathrm{mg}$ $\mathrm{P} \mathrm{kg}^{-1}$ soil) at 60 days after transplanting. For a given Glomus, columns (Mmos, Mintr $\mathrm{A}_{4}$ or $\mathrm{MintraB}_{1}$ ) with the same letter do not differ significantly $(p<0.05)$. 
Results showed that G. mosseae was less efficient in promoting the growth of plants compared to $G$. intraradices $A_{4}$ or $G$. intraradices $B_{1}$. Some authors agree with our results and showed the beneficial effect of AMF on soils with low $P$ levels (Martins et al., 2000; Gupta et al., 2002; Kapoor et al., 2007).

At the end of the growth period (60 days after transplanting), MintraA $\mathrm{A}_{4}$ had the highest mycorrhizal dependence (Table 2). This can be related to inoculum efficiency and/or inoculation percent. Freitas et al. (2006) observed in Mentha arvensis that the lowest values of mycorrhizal dependence occurred when the plants were inoculated with $\mathrm{G}$. clarum and $\mathrm{G}$. margarita and cultivated with $50 \mathrm{mg} \mathrm{P} \mathrm{kg}^{-1}$ soil; the mycorrhizal dependence values increased with higher levels of $P$.

AMF symbiosis may improve nutrient uptake by improving the soil exploration and contributes to enhance the growth and the vigor of plants (Beltrano \& Ronco, 2008). K content significantly increased in inoculated plants compared to non-inoculated ones, regardless of the $P$ level. Potassium content in MintraA $_{4}$ was $45 \%$ greater than that in non-inoculated plants, whereas in Mmos and MintraB $\mathrm{B}_{1}$ this increase was about $25 \%$ (Table 3 ). The increase in $\mathrm{K}$ content was associated with a significant increase in shoot dry weight as previously observed by Freitas et al. (2006) and Siqueira et al. (2002).

Mycorrhizal plants consistently accumulated more quantities of phosphorus in their shoots than non-mycorrhizal plants, regardless of $P$ availability. At low phosphorus levels, $P$ content was enhanced by the inoculation (Mmos: $37 \%$, MintraA $\mathrm{A}_{4}: 19 \%$ and MintraB $1: 13 \%$ ), compared to non-inoculated plants. Meanwhile, at high P level, the phosphorus content was significantly higher than in $-\mathrm{P}, 44 \%, 17 \%, 37 \%$ and $39 \%$ in NI, Mmos, MintraA ${ }_{4}$ and MintraB $_{1}$, respectively (Table 3 ). Ca content was higher in inoculated plants compared to non-inoculated ones.
Marschner \& Dell (1994) determined that AMF could be responsible for mineral absorption of about $80 \%$ of $P$ and $10 \%$ of $K$. Our findings indicated that AMF colonization had a beneficial effect on plant growth and $\mathrm{P}, \mathrm{Ca}$ and $\mathrm{K}$ absorption, in concordance with Chen et al. (2010) and Freitas et al. (2006).

We found that $\mathrm{N}$ was not modified by mycorrhizal or by $\mathrm{P}$ fertilizer (Table 3). In contrast, our results did not agree with those reported by Chen et al. (2010) and Freitas et al. (2006), who showed that mycorrhizal plants increased $\mathrm{N}$ content in the shoot.

The increase in nutrient uptake and growth, by AMF colonization, was demonstrated especially under low $P$ availability, although the extents of the colonization and the increase in growth parameters differ between host plants, species of AMF, and environmental conditions (Klironomos, 2003). Gupta et al. (2002) concluded that different cultivars of mint plants differ in nutrient uptake, and the mycorrhizal enhancement for the nutrient uptake was more pronounced in $\mathrm{P}$ than in $\mathrm{N}$ and $\mathrm{K}$. Moreover, Marschner \& Dell (1994) reported that the highest growth in mycorrhizal plants was caused by increased $P$ absorption, particularly from sparingly soluble $P$ sources.

Essential oils are a volatile lipophilic mixture of compounds from secondary plants, mostly consisting of monoterpenes, sesquiterpenes and phenylproponoids. These compounds derive from isopentenyl pyrophosphate (IPP) and dimethylally pyrophosphate (DMAPP). Hence, the biosynthesis of essential oils depends on the inorganic phosphorus content in the plant (Loomis \& Corteau, 1972). Phosphorus is also known to have multifarious cellular functions in plants, including: signaling and transmembrane metabolic flux; therefore, the secondary metabolism is modulated by these mechanisms (Ram et al., 2003).

TABLE 2. Growth parameters (fresh weight, FW; dry weight, DW and leaf area, LA) and mycorrhizal dependence (MD\%) in Mentha piperita plants, non-inoculated (NI) or inoculated with Glomus mosseae (Mmos), Glomus intraradices $\mathrm{A}_{4}\left(\right.$ MintrA $\left._{4}\right)$ and Glomus intraradices $\mathrm{B}_{1}\left(\right.$ MintraB $\left._{1}\right)$ with two $\mathrm{P}$ levels (-P: $10 \mathrm{mg} \mathrm{P} \mathrm{kg}^{-1}$ soil, $+\mathrm{P}: 40 \mathrm{mg} \mathrm{P} \mathrm{kg}^{-1}$ soil); 60 days after transplanting.

\begin{tabular}{|c|c|c|c|c|c|c|c|c|}
\hline \multirow[t]{2}{*}{ Treatments } & \multicolumn{2}{|c|}{$\mathrm{FW}\left(\mathrm{g} \mathrm{pl}^{-1}\right)$} & \multicolumn{2}{|c|}{$\mathrm{DW}\left(\mathrm{g} \mathrm{pl}^{-1}\right)$} & \multicolumn{2}{|c|}{$\mathrm{LA}\left(\mathrm{cm}^{2} \mathrm{pl}^{-1}\right)$} & \multicolumn{2}{|c|}{ MD (\%) } \\
\hline & $-P$ & $+P$ & $-P$ & $+P$ & $-P$ & $+P$ & $-P$ & $+P$ \\
\hline $\mathrm{NI}$ & $34.03 a A$ & $44.03 a B$ & 7.94aA & $10.93 a B$ & $815 a A$ & $1062 a B$ & -- & -- \\
\hline Mmos & $43.36 \mathrm{bA}$ & $58.34 \mathrm{bB}$ & $10.00 \mathrm{bA}$ & $13.91 \mathrm{bB}$ & $950 \mathrm{aA}$ & $1451 \mathrm{bB}$ & $20.1 a$ & $21.4 a$ \\
\hline $\mathrm{MintraA}_{4}$ & $42.74 \mathrm{bA}$ & $67.21 \mathrm{cB}$ & $10.59 \mathrm{bA}$ & $16.00 \mathrm{cB}$ & $1173 b A$ & $1804 d B$ & $25.0 \mathrm{~b}$ & $31.6 c$ \\
\hline MintraB $_{1}$ & $46.75 \mathrm{bA}$ & $60.98 \mathrm{bB}$ & $10.58 \mathrm{bA}$ & $15.22 \mathrm{bcB}$ & $1215 b A$ & $1614 \mathrm{cB}$ & $24.9 b$ & $28.2 b c$ \\
\hline C.V. $\%$ & 12.52 & 15.22 & 13.8 & 15.53 & 21.82 & 18.74 & -- & --- \\
\hline
\end{tabular}

\#Means followed by the same letter, uppercase letters on the line and lowercase letters in the column, for each evaluated parameter are not significantly different according to Tukey's test $(5 \%)$.

Rev. Bras. PI. Med., Botucatu, v.14, n.4, p.692-699, 2012. 
TABLE 3. Mineral ion content in shoots of Mentha piperita plants $\left(\mathrm{g} \mathrm{kg}^{-1} \mathrm{DW}\right)$, non-inoculated (NI) or inoculated with Glomus mosseae (Mmos), Glomus intraradices $\mathrm{A}_{4}\left(\right.$ Mintr $\left._{4}\right)$ and Glomus intraradices $\mathrm{B}_{1}\left(\mathrm{MintraB}_{1}\right)$ with two $\mathrm{P}$ levels (-P: $10 \mathrm{mg} \mathrm{P} \mathrm{kg}^{-1}$ soil, $+\mathrm{P}: 40 \mathrm{mg} \mathrm{P} \mathrm{kg}^{-1}$ soil); 60 days after transplanting.

\begin{tabular}{|c|c|c|c|c|c|c|c|c|}
\hline \multirow[t]{2}{*}{ Treatments } & \multicolumn{2}{|c|}{$\mathrm{K}\left(\mathrm{g} \mathrm{kg}^{-1} \mathrm{DW}\right)$} & \multicolumn{2}{|c|}{$P\left(g^{-1} \mathrm{Dg}\right)$} & \multicolumn{2}{|c|}{$\mathrm{Ca}\left(\mathrm{g} \mathrm{kg}^{-1} \mathrm{DW}\right)$} & \multicolumn{2}{|c|}{$N\left(\mathrm{~g} \mathrm{~kg}^{-1} \mathrm{DW}\right)$} \\
\hline & $-P$ & $+P$ & $-P$ & $+P$ & $-P$ & $+P$ & $-P$ & $+P$ \\
\hline $\mathrm{NI}$ & $13.5 \mathrm{aA}$ & $14.2 \mathrm{aA}$ & $1.6 \mathrm{aA}$ & $2.3 a B$ & $8.5 \mathrm{aA}$ & $8.6 \mathrm{aA}$ & $25.9 a A$ & $25.6 a A$ \\
\hline Mmos & $17.5 \mathrm{bA}$ & $18.1 \mathrm{bA}$ & $2.2 \mathrm{cA}$ & $2.6 \mathrm{bB}$ & $9.9 \mathrm{bB}$ & $9.4 \mathrm{bA}$ & $28.7 \mathrm{bB}$ & $27.1 \mathrm{bA}$ \\
\hline Mintra $\mathrm{A}_{4}$ & $19.6 \mathrm{cA}$ & $20.4 \mathrm{cA}$ & $1.9 \mathrm{bA}$ & $2.6 \mathrm{bB}$ & $10.3 \mathrm{bA}$ & $10.0 \mathrm{cA}$ & $26.1 \mathrm{aA}$ & $28.2 \mathrm{bB}$ \\
\hline Mintra $B_{1}$ & $16.8 \mathrm{bA}$ & $18.6 \mathrm{bB}$ & $1.8 \mathrm{bA}$ & $2.5 \mathrm{bB}$ & $10.2 \mathrm{bA}$ & $10.7 \mathrm{~dB}$ & $26.8 \mathrm{aB}$ & $24.3 a A$ \\
\hline C.V. (\%) & 15.2 & 14.28 & 12.56 & 5.79 & 10.34 & 8.73 & 7.18 & 7.41 \\
\hline
\end{tabular}

\#Means followed by the same letter, uppercase letters on the line and lowercase letters in the column, for each evaluated parameter are not significantly different according to Tukey's test $(5 \%)$.

The biosynthesis of secondary metabolites and, consequently, active ingredients in medicinal and aromatic plants depends on genetic, physiological and environmental factors. The concept of improving the levels of secondary plant metabolites through AMF is quite new; in recent years some research on this topic has been done. Studies focused on the accumulation of secondary compounds (essential oils) in the shoot of AMF-inoculated aromatic herbs.

Our results showed that the essential oil content (mL $\left.100 \mathrm{~g} \mathrm{~g}^{-1} \mathrm{DW}\right)$ significantly increased in mycorrhizal plants, regardless of the $P$ level and the fungal species (Table 4), in agreement with Sirohi \& Singh (1983), Gupta et al. (2002) and Copetta et al. (2006). Toussaint et al. (2007) in sweet basil and Khaosaad et al. (2006) in oregano plants have shown that the increased accumulation of phytochemicals in mycorrhizal plants is mediated by direct effects of the AMF and is not solely the indirect results of improved $\mathrm{P}$ nutrition.

On the other hand, the results showed that essential oil yield per plant $\left(\mathrm{mL}\right.$ plant $\left.^{-1}\right)$ increased significantly with increased $P$ level and inoculation. At $+P$ treatment, the essential oil yield significantly increased in both non-inoculated and inoculated plants compared to -P treatment. In non-inoculated plants the essential oil yield increment was by $33 \%$, whereas in Mmos, by $44 \%$, in MintraA $_{4}$, by $50 \%$ and MintraB $_{1}$, by $47 \%$. Plants inoculated with MintraA showed a significant increase in essential oil yield in comparison with other treatments (e.g. the increment was $51 \%$ at low $\mathrm{P}$ level and $67 \%$ at high $\mathrm{P}$ level, compared to $\mathrm{NI}$ ). The interaction AMF $\times \mathrm{P}$ was positive.

Mycorrhization significantly increased essential oil content in $M$. piperita compared to nonmycorrhizal plants, such as Ocimum vulgare ( Khaosaad et al., 2006; Rasouli-Sadaghiani et al., 2010), M. arvensis (Freitas et al., 2004) or Artemisia annua (Kapoor et al., 2007), but also in M. piperita.

Positive significant relationships were observed in inoculated plants between essential oil yield and colonization, as well as shoot dry weight. These results are in agreement with those reported by Praszna \& Bernath (1993), who determined that plants grown under deficient nutrient conditions show less essential oil production, and with those reported by Maia (1998) who stated that the deficiencies in $\mathrm{N}$ and $\mathrm{P}$ drastically reduced the production of fresh

TABLE 4. Essential oil (EO) content and essential oil yield in shoots of Mentha piperita plants, non-inoculated (NI) or inoculated with Glomus mosseae (Mmos), Glomus intraradices $\mathrm{A}_{4}\left(\mathrm{Mintr}_{4}\right)$ and Glomus intraradices $\mathrm{B}_{1}\left(\mathrm{MintraB}_{1}\right)$ with two $P$ levels (-P: $10 \mathrm{mg} \mathrm{P} \mathrm{kg}^{-1}$ soil, $+\mathrm{P}: 40 \mathrm{mg} \mathrm{P} \mathrm{kg}^{-1}$ soil); 60 days after transplanting.

\begin{tabular}{lcccc}
\hline \multirow{2}{*}{ Treatments } & \multicolumn{1}{c}{ EO content $\left(\mathrm{mL} 100 \mathrm{~g}^{-1} \mathrm{DW}\right)$} & \multicolumn{2}{c}{ EO yield $\left(\mathrm{mL} \mathrm{plant}^{-1}\right)$} \\
\cline { 2 - 5 } & $-\mathrm{P}$ & $+\mathrm{P}$ & $-\mathrm{P}$ & $+\mathrm{P}$ \\
\hline $\mathrm{NI}$ & $1.47 \mathrm{aA}$ & $1.49 \mathrm{aA}$ & $0.12 \mathrm{aA}$ & $0.16 \mathrm{aB}$ \\
Mmos & $1.63 \mathrm{bA}$ & $1.65 \mathrm{bA}$ & $0.16 \mathrm{bA}$ & $0.23 \mathrm{bB}$ \\
Mintra A 4 & $1.67 \mathrm{bA}$ & $1.70 \mathrm{bA}$ & $0.18 \mathrm{bA}$ & $0.27 \mathrm{cB}$ \\
Mintra $\mathrm{B}_{1}$ & $1.65 \mathrm{bA}$ & $1.67 \mathrm{bA}$ & $0.17 \mathrm{bA}$ & $0.25 \mathrm{bcB}$ \\
\hline C.V. $(\%)$ & 7.67 & 18.47 & 7.93 & 20.87 \\
\hline
\end{tabular}

\#Means followed by the same letter, uppercase letters on the line and lowercase letters in the column, for each evaluated parameter are not significantly different according to Tukey's test (5\%). 
matter. Piccaglia et al. (1993) also determined that the essential oil content in mint significantly increased with increasing rates of fertilizer probably due to the higher growth rate. Moreover, Freitas et al. (2004) reported that in $M$. arvensis, when phosphorus was not added to the substratum, the essential oil content increased by up to $89 \%$ in mycorrhizal plants, compared to noninoculated ones. No increment in essential oil content occurred when the levels of $\mathrm{P}$ increased. On the other hand, our results are in disagreement with those of David et al. (2006), who determined that plants of Mentha piperita subjected to $7.75 / 15.5 \mathrm{mg} \mathrm{L}^{-1}$ of $P$ showed a higher increase in essential oil content than those grown at $23.0 / 46.5 \mathrm{mg} \mathrm{L}^{-1}$ of $\mathrm{P}$.

Alsafar \& Al-Hassan (2009) stated that nitrogen and phosphorus fertilizers play a vital role in enhancing mint crop yield. Application of $75 / 50 \mathrm{~kg} \mathrm{~N} /$ $\mathrm{P}_{2} \mathrm{O}_{5}$ ha $^{-1}$ significantly increased total dry weight and essential oil yield.

Our results showed that there was a significant increase in EO content and yield in mycorrhizal plants, which was related to an increase in shoot fresh and dry weight and $\mathrm{P}$ content.

\section{CONCLUSION}

Mycorrhizal colonization and $\mathrm{P}$ supply have a beneficial effect in Mentha piperita $L$, enhancing nutrient absorption ( $\mathrm{Ca}, \mathrm{K}$ and $\mathrm{P}$ ), shoot dry weight and essential oil yield. Among the studied fungi, inoculation of $M$. piperita with Glomus intraradices $\mathrm{A}_{4}$ resulted in a significant increase in shoot dry weight and mycorrhizal dependence essential oil yield compared to the $G$. mosseae and $G$. intraradices $B_{1}$. Colonization of roots with Glomus intraradices $\mathrm{A}_{4}$ was higher than with other AMF, which may show an efficient symbiotic potential of this fungus with $M$. piperita. AMF inoculation increases the productivity and reduces the fertilizer application required to obtain economic production of peppermint crop.

\section{ACKNOWLEDGMENT}

To O. Peluso and L. Wanhan (CONICET) for technical assistance; to C. Moreno (CIC BA) for the English revision; E. Soto and L. Coelho for his translation of the abstract to Portuguese and to the Universidad Nacional de La Plata and CIC-PBA for financial support. M. Ronco and J. Beltrano are researchers of CIC-PBA.

\section{REFERENCE}

ABDUL-KHALIQ, K.K.; GUPTA, M.L.; KUMAR, S. The effect of vesicular-arbuscular mycorrhizal fungi on growth of peppermint. Indian Phytopathology, v.54, p.82-4, 2001.
ALSAFAR, M.S.; AL-HASSAN, Y.M. Effect of nitrogen and phosphorus fertilizers on growth and yield of indigenous mint (Mentha longifolia L.). Biotechnology, v.8, p.380-4, 2009.

AZCÓN-AGUILAR, C.; BAREA, J.M. Applying biotechnology to horticulture: significance and potentials. Scientia Horticulturae, v.68, p.1-24, 1997.

BAREA, J.M.; AZCON-AGUILAR, C.; AZCON, R. Efecto de la interacción de fertilizantes solubles de $\mathrm{P}$ y micorrizas sobre la nodulación, micorrización, crecimiento y nutrición de la alfalfa (Medicago sativa L.). Ciencia del Suelo, v.1, p.39-43, 1983.

BELTRANO, J.; RONCO, M.G. Improved tolerance of wheat plants (Triticum aestivum L.) to drought stress and rewatering by the arbuscular mycorrhizal fungus Glomus claroideum: Effect on growth and cell membrane stability. Brazilian Journal of Plant Physiology, v.20, p.2937, 2008.

BRESSAN, W. et al. Fungos micorrízicos e fósforo, no crescimento, nos teores de nutrientes e na produção do sorgo e soja consorciados. Pesquisa Agropecuária Brasileira, v.36, p.315-23, 2001.

CABELLO, M. et al. Effect of an arbuscular mycorrhizal fungus, Glomus mossae, and a rock-phosphatesolubilizing fungus, Penicillium thomii, on Mentha piperita growth in a soilless medium. Journal of Basic Microbiology, v.45, p.182-9, 2005.

CHEN, M.M. et al. C:N:P stoichiometry and specific growth rate of clover colonized by arbuscular mycorrhizal fungi. Plant and Soil, v.326, p.21-9, 2010.

CLEMENT, C.R.; HABTE, M. Genotypic variation in vesicular-arbuscular mycorrhizal dependence of the pejibaye palm. Journal of Plant Nutrition, v.18, p.190716, 1995.

COPETTA, A.; LINGUA, G.; BERTA, G. Effects of three AM fungi on growth, distribution of glandular hairs, and essential oil production in Ocimum basilicum L. Var. Genovese. Mycorrhiza, v.16, p.485-94, 2006.

DAVID, E.F.; BOARO, C.S.; MARQUES, M.O. Rendimento e composição do óleo essencial de Mentha piperita L., cultivada em solução nutritiva com diferentes níveis de fósforo. Revista Brasileira de Plantas Medicináis, v.8, p.183-8, 2006.

DERWICH, E.; BENZIANE, Z.; BOUKIR, A. Antibacterial activity and chemical composition of the leaf essential oil of Mentha rotundifolia from Morocco. Electronic Journal of Environment, Agriculture and Food Chemistry, v.9, p.19-28, 2010.

FREITAS, M.S.; MARTINS, M.A.; VIEIRA, I.J.C. Produção e qualidade de óleos essenciais de Mentha arvensis em resposta à inoculação de fungos micorrízicos arbusculares. Pesquisa Agropecuária Brasileira, v.39, p.887-94, 2004.

FREITAS, M.S.; MARTINS, M.A.; CARVALHO, A.J.C. Crescimento e composição da menta em resposta à inoculação com fungos micorrízicos arbusculares e adubação fosfatada. Horticultura Brasileira, v.24, p.116, 2006.

GUPTA, M.L. et al. Effect of vesicular-arbuscular mycorrhizal (VAM) fungus Glomus fasciculatum on the essential oil yield related characters and nutrient acquisition in the crops of different cultivars of menthol mint (Mentha arvensis) under field conditions. 
Bioresource Technology, v.81, p.77-9, 2002.

HADDAD, K.S.; HIGGINSON, F.R. Methods of plant chemical analysis. Sydney: NSW Agriculture and Fisheries, 1990. 28p.

HODGE, A. Microbial ecology of the arbuscular mycorrhiza. Microbial Ecology, v.32, p.91-6, 2000.

JACKSON, L.E.; MILLER, D.; SMITH, S.E. Arbuscular mycorrhizal colonization and growth of wild and cultivated lettuce in response to nitrogen and phosphorus. Science Horticulturae, v.94, p.205-18, 2002.

KAPOOR, R.; CHAUDHARY, V.; BHATNAGAR, A. Effects of arbuscular mycorrhiza and phosphorus application on artemisinin concentration in Artemisia annua L. Mycorrhiza, v.17, p.581-7, 2007.

KHAOSAAD, T. et al. Arbuscular mycorrhiza alter the concentration of essential oils in oregano (Origanum sp., Lamiaceae). Mycorrhiza, v.16, p.443-6, 2006.

KITSON, R.E.; MELLON, M.F. Calorimetric determination of $P$ as a molybdovanadate phosphoric acid. Industrial \& Engineering Chemistry Analytical Edition, v.16, p.37983, 1944.

KLIRONOMOS, J.N. Variation in plant response to native and exotic arbuscular mycorrhizal fungi. Ecology, v.84, p.2292-301, 2003.

KUMAR, S.; WAHAB, N.; WARIKOO, R. Bioefficacy of Mentha piperita essential oil against dengue fever mosquito Aedes aegypti L. Asian Pacific Journal of Tropical Biomedicine, v.1, p.85-8, 2011.

LOOMIS, W.D.; CORTEAU, R. Essential oil biosynthesis. Recent Advances in Phytochemistry, v.6, p.147-85, 1972. MAIA, N.B. Efeito da nutrição mineral na qualidade do óleo essencial da menta (Mentha arvensis L.) cultivada em solução nutritiva. In: MING, L.C. et al. (Eds.). Plantas medicinais aromáticas e condimentares: avanços na pesquisa agronômica. Botucatu: FCA-UNESP, 1998. p.81-95.

MARSCHNER, H.; DELL, B. Nutrient uptake in mycorrhizal symbiosis. Plant and Soil, v.159, p.89-102, 1994.

MARTINS, M.A.; GONCALVES, G.F.; SOARES, A.C.F. Efeito de fungos micorrízicos arbusculares associados a compostos fenólicos, no crescimento de mudas de mamoreiro. Pesquisa Agropecuaria Brasileira, v.35, p.1465-71, 2000.

NOGUEIRA, M.A.; CARDOSO, E.J.B. Produção de micélio externo por fungos micorrízicos arbusculares e crescimento de soja em função de doses de fósforo. Revista Brasileira de Ciência do Solo, v.24, p.329-38, 2000.

PHILLIPS, J.; HAYMAN, D. Improved procedure for clearing roots and staining parasitic and vesicular arbuscular mycorrhizal fungi for rapid assessment of infection. Transaction of the British Mycological Society, v.55, p.158-61, 1970.

PICCAGLIA, R. et al. Agronomic factors affecting the yields and essential oil composition of peppermint (Mentha $\mathrm{x}$ piperita L.). Acta Horticulturae, v.344, p.29-30, 1993. PRASZNA, L.; BERNATH, J. Correlations between the limited level of nutrition and essential oil production of peppermint. Acta Horticulturae, v.344, p.278-89, 1993. RAM, M. et al. Foliar application of phosphate increased the yield of essential oil in menthol mint (Mentha arvensis). Australian Journal of Experimental Agriculture, v.43, p.1263-8, 2003.

RASOULI-SADAGHIANI, M. et al. Effects of arbuscular mycorrhizal (AM) fungi on growth, essential oil production and nutrients uptake in basil. Journal of Medicinal Plants Research, v.4, p.2222-8, 2010.

SIQUEIRA J.O.; LAMBAIS, M.R.; STÜRMER, S.L. Fungos micorrízicos arbusculares: características, simbiose e aplicação na agricultura. Biotecnología Ciencia e Desenvolvimiento, v.25, p.12-21, 2002.

SIROHI, S.S.; SINGH, O.S. Relationship of endomycorrhizal association of unsterilized soils with available soil phosphorus, plant growth, phosphorus uptake and oil synthesis in peppermint. Scientia Horticulturae, v.20, p.185-91, 1983.

SOKOVIÆE, M.D. et al. Chemical composition of essential oils of Thymus and Mentha species and their antifungal activities. Molecules, v.14, p.238-49, 2009.

SOUZA, M.P.; MATOS, N.O.; MATOS, F.J.A. Constituintes químicos ativos de plantas medicinais brasileiras. Fortaleza: Imprensa Universitária/UFC, 1991. 416p. TOUSSAINT, J.P.; SMITH, F.A.; SMITH, S.E. Arbuscular mycorrhizal fungi can induce the production of phytochemicals in sweet basil irrespective of phosphorus nutrition. Mycorrhiza, v.17, p.291-7, 2007. WOLF, D.C. et al. Influence of sterilization methods on selected soil microbiological, physical and chemical properties. Journal of Environmental Quality, v.18, p.3944, 1989. 